\title{
POLITICAL TALK, CONVERSATION, DISCUSSION, DEBATE, OR DELIBERATION?: AN INTERPERSONAL POLITICAL COMMUNICATION DEFINITION AND TYPOLOGY
}

\author{
¿CHARLA POLÍTICA, CONVERSACIÓN, DISCUSIÓN, \\ DEBATE O DELIBERACIÓN?: \\ UNA DEFINICIÓN Y TIPOLOGÍA DE LA COMUNICACIÓN \\ POLÍTICA INTERPERSONAL
}

\author{
Juan S. Larrosa-Fuentes \\ Instituto Tecnológico y de Estudios Superiores de Occidente, México \\ ORCID: https://orcid.org/0000-0003-1529-5107 \\ Autor para correspondencia: Juan S. Larrosa-Fuentes, email: larrosa@iteso.mx
}

\begin{abstract}
Interpersonal communication is at the core of every form of human communication system, and the realm of political communication is no exception. Through interpersonal communication, individuals gain knowledge about the political world, understand the common goals and values of their political system, and learn how to participate in political tasks. As do many other research areas, interpersonal communication research faces numerous challenges. There is a lack of conceptual organization and precision about names and labels such as political talk, political conversation, public dialogue, political dialogue, political discussion, political debate, and political deliberation. Apparently, these expressions refer to the same idea: interpersonal communications that fall into the political realm. However, each term has a diverse epistemological, normative, and theoretical background and represents a different way of conceptualizing this idea. This essay suggests a general definition for interpersonal political communication and a matrix that organizes the existing academic knowledge about this topic.
\end{abstract}

Keywords: political communication, interpersonal communication, deliberation, public dialogue, political discussion

Global Media Journal México 17(33). julio - diciembre 2020. Pp. 1-19. 


\section{Resumen}

La comunicación interpersonal es central para cualquier sistema de comunicación y el ámbito de la comunicación política no es la excepción. A pesar de la importancia de la comunicación interpersonal, el campo de la comunicación política ha asignado poca importancia al estudio de este tipo de comunicación. Por ello, la investigación sobre comunicación interpersonal enfrenta numerosos desafíos. En específico, existe una falta de organización y, por tanto, de precisión, en la distinción de conceptos como discurso político, conversación política, diálogo público, diálogo político, discusión política, debate político y deliberación política. Aparentemente, estas expresiones se refieren a la misma idea: comunicaciones interpersonales que caen en el ámbito político. Sin embargo, cada término tiene un trasfondo epistemológico, normativo y teórico diverso y representa una forma diferente de conceptualizar esta idea. Este trabajo sugiere una definición general de comunicación politica interpersonal y una matriz que organiza la desorganización conceptual previamente mencionada.

Palabras clave: comunicación política, comunicación interpersonal, deliberación, diálogo público, discusión política.

Recibido: 27/08/2020

Aceptado: 15/10/2020

Interpersonal communication is at the core of every form of human communication system, and the realm of political communication is no exception. The most significant and complex political communication systems, such as those that operate in contemporary and advanced democracies, are informed by several interpersonal communication practices that work in combination with other forms of communication (i.e., group, mass, and network communication). Through interpersonal communication, individuals gain knowledge about the political world, understand the common goals and values of their political system, and learn how to participate in political tasks.

Despite the importance of interpersonal communication, political communication scholarship has assigned little priority to study these forms of communicative practices until recent decades (Eveland et al., 2011, p. 1082). For many years, mass political communication research captured the attention of political scientists, sociologists, psychologists, and communication scholars. This situation has changed and now interpersonal communication has become a vibrant field within political communication 
research, where it is possible to find various theoretical and methodological approaches to understanding how people perform interpersonal interactions within a political context (McLeod et al., 2008, p. 235).

As do many other research areas, interpersonal communication research faces numerous challenges. One of these challenges is to clarify the vocabulary that scholars have used for naming and describing interpersonal political communication. In particular, there is a lack of conceptual organization and precision about names and labels such as political talk, political conversation, public dialogue, political dialogue, political discussion, political debate, and political deliberation. Apparently, these expressions refer to the same idea: interpersonal communications that fall into the political realm. However, each term has a diverse epistemological, normative, and theoretical background and represents a different way of conceptualizing this idea.

This essay attempts to organize the existent knowledge about interpersonal political communication. This effort does not intend to eliminate, blur, or fuse the epistemological, normative, and theoretical differences that are located in all the ways of naming individuals' political interactions in their daily lives. Thus, the two main objectives of this paper are to a) define interpersonal political communication, and to $b$ ) provide a proposal for stabilizing the vocabulary that refers to its different forms.

This paper comprises six sections. The first section analyzes the main concepts that refer to interpersonal political communication. The second and third sections are concerned with defining interpersonal political communication. The fourth section presents a proposal to organize the forms of interpersonal political communication through a classification matrix. Last, in the fifth section, the conclusions are presented.

\section{Interpersonal Political Communication's Various Names}

It is relevant to begin with the following statement, although it may seem obvious: Interpersonal communication is one of the various political communication practices. No one would deny this statement. The problems begin when scholars choose one label or another for naming interpersonal political communication (e.g., political talk, political conversation, public dialogue, deliberation). Until now, there has been no consensus on how to name and define interpersonal political communication. The second problem, which is more important than the first one, is the question of what types of communication practices count as interpersonal political communication, as well as why and how 
scholars should study these processes. These problems are due to different epistemological and theoretical positions about communication and politics, positions that are briefly described in the following pages.

The literature that deals with interpersonal political communication is divided into four main theoretical branches: critical theory, social cognitive theory, persuasion theory, and rational choice theory. These theoretical branches all understand interpersonal communication as a process within the realm of political communication. An essential commonality in these four intellectual traditions is the pervasive presence of Jürgen Habermas's theories of the public sphere and communicative action (1962, 1985b, 1985a, 2006). Scholars use Habermas's critical ideas either to embrace them or to reject them.

The Structural Transformation of the Public Sphere (1962) is considered the first influential work of Habermas. This book contains a historical investigation of 18thcentury European life in which this author explains the emergence of the bourgeois public sphere. As the bourgeois obtained more power in modern European societies, political discussions (i.e., interpersonal and group political communications) were translated from the imperial courts and private spaces to Paris and London's coffeehouses and salons. That is, political communication gained a public status. Thus, Habermas (2006, p. 412) argues that the public sphere is the communicative space between the state and society.

The public sphere concept is relevant because it creates the distinction between public and private and suggests that political communication occurs only in the public sphere. Within the public sphere, the ideal interpersonal communication, as well as mass communication in contemporary societies, should be performed under the standards of deliberative democracy. Habermas, who is concerned with normative theory, asserts that political communication (i.e., deliberation) should be public and transparent; also, in these communicative processes, individuals should have equal opportunities for participation as well as a shared understanding and agreement about the use of reasonable arguments during the deliberation. Habermas contends that, from a normative point of view, interpersonal political communication ought to be carried out through deliberation. Therefore, Habermas sets the standards for understanding and analyzing interpersonal political communication. However, he also poses a philosophical problem that is frequently overlooked: the gap between the "is" and the "ought"-in other words, what interpersonal political communication actually is, and what it ought to be. Habermas is without a doubt concerned with what interpersonal political communication ought to be. 
Numerous scholars have sympathized with the aforementioned Habermasian ideas and have suggested that political communication (i.e., group, mass, and network) ought to be studied under deliberative standards. For example, Robert Goodin $(2012$, 2017) has explained that interpersonal political communication leads to more informed and better-structured opinions among individuals who interact. James S. Fishkin and (other) colleagues have proposed "deliberative polls" as a means to enhance mass deliberation in contemporary democracies - deliberative polls as processes where citizens receive information about a political issue and then deliberate about this issue through interpersonal communication (Chirawurah et al., 2019; Fishkin \& Laslett, 2003; Fishkin \& Luskin, 2005; N. Kim et al., 2018). Druckman and Nelson (2003) have found that deliberation among citizens eliminates elite framing effects. And, in a recent literature review, scholars explain that "ordinary people are capable of high-quality deliberation, especially when deliberative processes are well-arranged" (Dryzek et al., 2019, p. 1145). Although the literature review in the current paper is not exhaustive, the references cited above are sufficient to give a sense of critical theory's influence on contemporary research on interpersonal political communication.

A second set of scholars embrace Habermas's theory, but only as a utopian horizon in political communication (Dahlgren, 2005 , p. 156) that cannot be reached. These scholars advance arguments against Habermas's communication theories. These counterarguments, which draw from social cognitive theory, persuasion theory, and rational choice theory, can be summarized in three main ideas. First, critical and normative theorists fail to develop theoretical concepts to understand how individuals communicate in the real world. The gap between the "is" and the "ought" could be unbridgeable when theoretical concepts are needed to develop empirical research designs. Second, critical and normative theories have led to narrowing interpersonal political communication to the investigation of the conversations among political elites (e.g., politicians, journalists, pundits). This constriction is harmful because interpersonal communication among ordinary citizens is also part of the political communication process, and, therefore, critical scholars should be studying these human interactions (Wyatt et al., 2000). Third, some scholars have warned that, in discussions about political communication, the distinction between public and private has become obsolete. Various political, economic, social, cultural, and technological changes have erased the public and private boundaries. Therefore, political communications also occur in the private realm (Bimber, 2012, p. 122; Stromer-Galley, 2002). 
The tensions, discussions, and debates about interpersonal political communication's empirical and normative characteristics are present in most of the last two decades' scholarship. These issues have led to a lack of a shared vocabulary for studying interpersonal political communication, and some authors have created their own definitions. Delli Carpini, Cook and Jacobs (2004) have proposed the concept of "discursive participation," which includes interpersonal communication as a form of political participation, and Dahlgren (2005) has suggested the idea of "civic cultures" for the study of online political interactions. However, most scholars have tended to use various terms for naming interpersonal political communication indistinguishably. In many papers, the term political talk is used as a label for interpersonal political communication (H. M. Kim \& Baek, 2018; J. Kim et al., 1999; J. Kim \& Kim, 2008; Morey \& Yamamoto, 2020; Pennington \& Winfrey, 2020; Rojas et al., 2011; Valeriani \& Vaccari, 2018; Wyatt et al., 2000). In the same fashion, the concept of political discussion is used widely to refer to interpersonal political communication among citizens (Amsalem \& Nir, 2019; Ikeda \& Boase, 2011; Morey \& Yamamoto, 2020; Settle \& Carlson, 2019; Street, 2016; Vliegenthart \& Zoonen, 2011) as well as the term political conversation (Glover, 2018; Shugars \& Beauchamp, 2019; Sørensen, 2016). In contrast, other researchers use, without distinction, terms such as deliberation, conversation, interpersonal communication, interpersonal exchanges, and/or political talk (e.g., Shah et al., 2007). In short, "the issue is complicated by the imprecise and shifting nature of the terms used to describe the nature of talk about political matters" (Wyatt et al., 2000, p. 72).

Hence, research on interpersonal political communication faces three critical issues. First, scholars of political communication have to reflect on the ethical and normative grounds of their scientific work. Scholars can be driven by normative claims-such as the deliberative Habermasians ones - or not. Their reflections should explicitly influence the definitions of what it is and not interpersonal political communication. Second, in the literature on interpersonal communication, there is no consensus about interpersonal political communication boundaries. Political communication is loosely defined: Some scholars use broad definitions, and others choose narrow meanings. This is problematic because there are no standard parameters for determining which human interactions fall into the realm of political communication. Third, scholars have failed to explicitly define interpersonal communication and describe how interpersonal communication operates in the political sphere.

Researchers who intend to study interpersonal political communication should 
individually resolve the first issue. They have to reflect about, and acknowledge, which political theory or orientation they embrace. As Althaus (2012) has explained, scholars should draw from some of the main theories of democracy (i.e., republicanism, pluralism, or elitism) to make evident and explicit their normative backgrounds. Therefore, this healthy tension between the "is" and the "ought" will continue defining and dividing the scholarship on interpersonal political communication. However, the second and third issues admit theoretical treatment. In the following sections, I will propose a definition of what should be counted as political communication and a definition of interpersonal communication. These definitions constitute the theoretical base for building a classification matrix of interpersonal political communication. This classification matrix offers a solution for stabilizing the vocabulary used to describe political conversations and deliberations.

\section{What Is (Interpersonal) Communication?}

Human communication is a practice where two or more individuals exchange information and symbolic forms (Craig, 1999). The outcome of these practices is the production of shared meanings. Communication, as a practice, can be performed on a micro (interpersonal communication), mezzo (group and organizational communication), and macro (mass and networked communication) scales.

In this context, interpersonal communication can be broadly defined as the practice of exchanging information and symbolic forms between two or more individuals. However, interpersonal communication varies from group communication, "where interaction is less focused on individuals and more toward a small number of people; [..] public communication, where one message is tailored to be delivered to many, usually as public speaking; or mass communication, where it is assumed that messages will be somewhat impersonal and capable of reproduction" (Manning, 2020, p. 842).

Through interpersonal communication, individuals enter into the social world and construct relationships with other individuals. They use this kind of interaction in their daily lives to understand their reality, obtain information about their social world, interact with their peers, "negotiate meanings and create shared understandings with one another" (Valo, 2011, p. 3).

Historically, the oldest form of interpersonal communication is that which occurs in a face-to-face situation, where individuals 
sustain a focused interaction through the reciprocal exchange of verbal and nonverbal cues. The following major characteristics distinguish this type of communication: 1) the presence of two or more individuals in physical proximity, 2) involved in focused interactions, supplying social cues for one another to act on, 3) with the focused interaction proceeding through an exchange of messages, 4) in face-toface encounters where all sense modalities can be exploited" (Blake, 1972).

However, interpersonal communication among individuals can also occur through the mediation of different technologies, such as letters, telegraphs, phone calls, walkie-talkies, emails, digital chats, social media, and so forth (Manning, 2020, p. 843). When mediated by such technologies, interpersonal communication can be an asynchronous practice that does not necessarily require physical proximity among the individuals.

In short, interpersonal communication is "a complex, situated social process in which people who have established a communicative relationship exchange messages in an effort to generate shared meanings and accomplish social goals" (Burleson, 2009, p. 151). These communicative relationships, which are communicative practices, can be held through face-to-face interactions and mediated by technologies.

\section{What is Interpersonal Political \\ Communication?}

Since ancient times, human beings have lived in communities as a means of self-preservation and social reproduction. Historically, these communities have adopted different forms of political organization through the distribution of social power, the allocation of scarce goods, the regulation of the use of violence, and other means. Several communicative practices enable the organization of these political communities. Thus, explicitly or implicitly, every political relation, organization, and/or system has a political communication system that allows its operation (Larrosa-Fuentes, 2017).

Individuals who interact with each other through various communicative practices are the units that constitute the political communication systems. Therefore, the individuals that are part of a political community are part, at the same time, of political communication systems, and the individuals that are part of a political community participate actively or inactively in the development of political communication systems. These communication systems, which have been historically present in all kinds of societies, can be observed on a micro (interpersonal communication), mezzo (group and institutional communication), and macro (mass and networked communication) scales. 
Political communication systems perform three main functions (LarrosaFuentes, 2017). First, these systems have an epistemic function (Habermas, 2006). Through communicative actions (e.g., deliberation), individuals generate knowledge about the rules of operation (norms or laws) and the common goals and values of a political system. Thus, political communication operates as a mechanism for producing political knowledge. In democratic systems, this epistemic function is at the core of the various processes of collective decision making. In contemporary societies, political knowledge is created in institutions such as parliaments, courts, administrative agencies, and governments. This knowledge takes various forms (e.g., laws, edicts, public policies) and is stored in multiple material and nonmaterial artifacts (e.g., books, newspapers, digital files). Second, political communication systems have the task of disseminating political knowledge among all the individuals who integrate a political community (Martín Serrano, 1994). In other words, political communication systems diffuse the political knowledge that individuals need for living according to the norms, laws, common goals, and values of a political community. Third, political communication systems function as a mechanism for organizing the collective actions that pursue the goals and realize the values of a political community (Martín Serrano, 1994). These functions have the final objective of reproducing, growing, and perpetuating a political community (Martín Serrano, 1994).

Concluding, from this brief exposition, political communication is defined as a social practice in which two or more individuals exchange information and symbolic forms to structure the production, reproduction, and control of political power (Larrosa-Fuentes, 2017). Political communication systems are organized sets of political communication practices performed by social actors who fight for communicative power and resources. These communicative practices, which are enacted and reenacted, build, over time, patterns, norms, and values that enable the system's operation (Chadwick, 2013, Chapter 1).

Following the previous definitions, we can conclude that interpersonal political communication is a complex and situated human practice performed by two or more individuals who are part of a political community and through face-to-face or mediated communication. This practice has the purpose of interchanging information and symbolic forms about the political system. This interchange of messages has three main functions: create political knowledge, diffuse political knowledge, and/or organize collective action. Interpersonal communication is different from other forms of communication, such as organizational or mass communication, due to its scale: 
interpersonal communication occurs at the individual level and not at the group or social levels.

Finally, it is relevant to provide a note regarding communication scales and their operation. The typology of interpersonal, group, organizational, mass, and networked communication is useful for distinguishing communication as a complex practice. In reality, the various forms of communication are intermeshed. Numerous interpersonal communication practices inform organizational, mass, and networked communication. For example, in a presidential debate, we can observe two candidates who are interchanging information and symbolic forms between them (i.e., an interpersonal political communication practice). The former communication practice is then mediatized through mass and digital communication. The mediatization of the debate structures and affects the interpersonal communication between candidates - which would be different if this communicative practice was held in a private and non-mediated environment. However, what it is essential here, is to stress that a presidential debate, which is traditionally (and correctly) conceptualized as mass communication, at the same time, is informed by interpersonal communication practices-practices that could be studied in the frame of interpersonal communication.

\section{Interpersonal Political Communication: A Classification Matrix}

As stated at the beginning, this essay has two main objectives: The first one has already been accomplished - that is, to offer a bounded definition of interpersonal political communication. Hence, drawing from this definition, the next step is to provide a solution for stabilizing the vocabulary that names interpersonal political communication forms. This paper suggests a classification matrix to achieve this objective. The matrix organizes the forms that interpersonal political communication presents within the social sciences and the humanities' research fields. This classification matrix is built along two dimensions: the institutional rules for performing interpersonal political communication (i.e., a continuum that extends from non-ruled communication to ruled communication) and the actors that are part of the aforementioned communicative processes (i.e., individuals and political elites).

\section{First Continuum: Form Non-Ruled to}

\section{Ruled Communication}

Scholars have identified interpersonal political communication as a range of practices, from a spontaneous act to a communicative act determined by rules. The non-ruled interpersonal political communication "is a

Global Media Journal México 17(33). julio - diciembre 2020. Pp. 1-19. 
nonstrategic and noninstrumental actionoriented to mutual understanding. The best example of communicative action is informal and spontaneous conversations through which people establish interpersonal relations" (J. Kim \& Kim, 2008, p. 55). Within this classification, non-ruled interpersonal political communication between two or more individuals has the following names: political talk, political conversation, political discussion, political dialogue, political debate, and non-instrumental deliberation.

An important point to keep in mind is that, although some communicative practices do not have explicit operation rules, this does not mean that these processes are purposeless. A communicative practice falls into the realm of political communication only if it satisfies one or more of the conditions outlined in the preceding section (i.e., production of political knowledge, distribution of political knowledge, and organization of collective actions driven by political knowledge). Suppose, for example, two individuals are having a conversation in the subway. They start talking about their daily routines, and suddenly the conversation shifts to another topic: the next presidential debate. Throughout the talk, both individuals gain and reproduce knowledge about the political system. Before this conversation, the individuals did not have in mind specific rules for performing this interaction, and they did not have any explicit goals to achieve. However, through this conversation they become part of a more extensive political communication system that produces and reproduces political knowledge.

In the continuum, deliberation appears to be in opposition to political discussion. On the one hand, deliberation is a reflective communicative practice bounded by explicit rules. Rules can structure the objectives, procedures, and desired outcomes of a communication practice. During a deliberative process, some standard rules include that the individuals who participate should be conscious of their participation. Likewise, all the individuals who participate in the communicative process should have the same opportunities for participation and contribute to the deliberation through rational argumentation. Finally, another common standard is that participants should be open to discussing arguments and embracing the best idea (Bohman, 2006). On the other hand, the rules that inform deliberations are crafted to accomplish specific goals, such as creating political knowledge and the production of collective decisions (J. Kim \& Kim, 2008).

\section{Second Continuum: Form Individuals to Political Elites}

An essential element about researching interpersonal political communication is related to who can be and who is part of a communicative interaction. According to the definition of interpersonal political 
communication provided in this paper, anyone who is part of a political community can participate in these communicative practices. However, within a political community not all individuals hold the same power. "This uneven distribution leads to the creation of elites, or relatively small groups of people who have a disproportionate level of influence and power over political outcomes" (Crandinetti, 2008). Political communication scholars claim that political elites have more power within a political communication system than the rest of the individuals that form a political community (Chadwick, 2013; StromerGalley, 2004).

Both political elites and individuals are part of the political communication system, and both can perform and take part in interpersonal political communication. Therefore, the second continuum of the classification matrix is related to the actors that perform interpersonal political communications. These actors are the political elites and the individuals who integrate a political community. The political elites include elected officials, public servants, politicians, candidates, journalists, and public intellectuals. Individuals are the rest of the persons who give form to a political community. Thus, communicative processes can occur between individuals, between political elites, and between individuals and political elites.

\section{The Classification Matrix}

Table 1.

Interpersonal Political Communication Classification Matrix

\begin{tabular}{|c|c|c|c|c|}
\hline & & Non-ruled & & Ruled \\
\hline Individuals & I. & $\begin{array}{l}\text { Non-ruled political } \\
\text { discussions between } \\
\text { individuals. }\end{array}$ & II. & $\begin{array}{l}\text { Ruled political deliberation } \\
\text { between individuals. }\end{array}$ \\
\hline $\begin{array}{l}\text { Individuals \& } \\
\text { Political Elites }\end{array}$ & III. & $\begin{array}{l}\text { Non-ruled political } \\
\text { discussions between } \\
\text { individuals and political } \\
\text { elites. }\end{array}$ & IV. & $\begin{array}{l}\text { Ruled political deliberations } \\
\text { between individuals and } \\
\text { political elites. }\end{array}$ \\
\hline Political Elites & V. & $\begin{array}{l}\text { Non-ruled political } \\
\text { discussions between } \\
\text { political elites. }\end{array}$ & VI. & $\begin{array}{l}\text { Ruled political deliberations } \\
\text { between political elites. }\end{array}$ \\
\hline
\end{tabular}


The classification matrix suggests six types of interpersonal political communication. In the first row of the matrix presents communication practices between individuals. These practices are vital within democratic institutions and social life at large. In their daily life, people talk about their political reality and discuss their political environment. Through these practices, individuals participate in broader political communication systems (i.e., mezzo and macro levels). Thus, the first element of the classification matrix refers to "political discussions between individuals". Henceforth, the term political discussion will refer to all the names that nonruled interpersonal political communication can take. These conversations can occur anywhere, in public and private spaces. Political discussions between individuals can be face-to-face or mediated by technologies such as letters, text messages, emails, phone calls, and more. There are many examples of this type of interpersonal political communication: a couple discussing national politics in their bedroom, two students exchanging emails about a presidential debate, two strangers talking about politics in a bar, and so forth.

"Deliberation between individuals" is the second element of the classification matrix. Here, in this type of interpersonal political communication, we are before a ruled communication between two individuals. These conversations occur mostly in public spaces and settings where people engage in communication practices bounded by specific rules. Deliberation between individuals occurs mainly through face-to-face, and technologies mediate some of them. For example, we can find a deliberation between individuals in a practice where two persons deliberate about politics on Reedit - a social media platform that has specific rules of operation. Another example could be two individuals deliberating in an organization such as a school or a neighborhood committee.

If we follow the actors' continuum, political elites appear as the opposite of individuals. Studying how elites interact is crucial for understanding how communication structures institutional and non-institutional processes that organize political power distribution. Thus, "political discussions between political elites", which are non-ruled practices, is the fifth element of the matrix. These conversations can occur anywhere, in public and private spaces. They can be face-toface or mediated by technologies such as letters, text messages, emails, phone calls, and more. A political discussion between elites can be observed during an off-the-record conversation between a journalist and a politician, a public conversation between journalists during a talk show; and through an email exchange between two congresspersons. At the other end of the nonruled-ruled continuum is "deliberation between political elites". These deliberations occur in public spaces and can be face-to-face or mediated by 
technologies. These deliberations are how contemporary democracies create the laws that rule society, find solutions for political problems, and promote collective actions. The most visible form of this communication occurs in parliaments, congresses, or courts. Examples of political discussions between political elites could be an exchange between two congresspersons in a parliament, a debate between two candidates, a deliberation between journalists and politicians during a television show.

There are two types of interpersonal political communication in the middle of the matrix that include interactions between individuals and political elites. Researching these interactions is also relevant in the realm of political communication because, through interpersonal exchanges, political elites learn what individuals think and want, and vice versa. In this context, "political discussions between individuals and political elites" is the third element of the matrix. These conversations usually are, but not exclusively, held in public spaces and can be face-to-face or mediated almost by any form of communication technologies. Some examples of these discussions could be a casual conversation between a congressperson and an individual during a radio show or a communicative exchange between a major and a citizen through a Facebook thread. The fourth element of the matrix is related to "deliberations between individuals and political elites". These conversations usually are, but not exclusively, held in public spaces. These conversations can be face-to-face or mediated communications. Examples of these deliberations could be observed during town hall meetings where a citizen deliberate with a congressperson; or deliberations in social media between political elites and individuals during an electoral campaign.

\section{Conclusions}

Interpersonal communication is a practice of any political communication system. Through interpersonal political communication, humans create political knowledge, diffuse this knowledge, and organize the collective tasks of a political community. Therefore, the investigation of interpersonal political communication processes is strategic for the advancement of political communication research.

This essay suggests that a route for improving the subfield of interpersonal political communication is organizing the existing knowledge. By and large, researchers do not provide clear and bounded definitions of interpersonal political communication. Moreover, there are many ways in which researchers name the various interpersonal political communication forms. 
In this context, this paper defines interpersonal political communication and presents a classification matrix of the various forms of this communicative. This classification proposes a way for organizing the knowledge that has been produced in the political communication field. Furthermore, this proposal suggests that scholars should be studying interpersonal political communication as a complex set of practices that take multiple forms, occur in different places, and are performed by many actors.
If the nominal disorganization about the labels assigned to interpersonal political communication is overcome, then it is easier to see that the diverse epistemological and theoretical approaches contribute different knowledge about interpersonal communication. In most cases, these types of knowledge are not mutually exclusive; instead, they are complementary. The classification could be used as a tool to overcome the nominal disorganization and, thus, for improving the subfield.

\section{References}

Althaus, S. L. (2012). What's good and bad in political communication research? Normative standards for evaluating media and citizen performance. In H. A. Semetko \& M. Scammell (Eds.), The SAGE handbook of political communication (pp. 97-112). SAGE.

Amsalem, E., \& Nir, L. (2019). Does interpersonal discussion increase political knowledge? A meta-analysis. Communication Research, 0093650219866357. https://doi.org/10.1177/0093650219866357

Bimber, B. (2012). Digital media and citizenship. In H. A. Semetko \& M. Scammell (Eds.), The SAGE handbook of political communication. SAGE.

Blake, R. H. (1972). Medio communication: A conceptualization. https://eric.ed.gov/?id=ED062785

Bohman, J. (2006). Deliberative democracy and the epistemic benefits of diversity. Episteme, 3(03), 175-191. https://doi.org/10.3366/epi.2006.3.3.175

Burleson, B. R. (2009). The nature of interpersonal communication. In C. R. Berger, M. E. Roloff, \& D. R. Ewoldsen (Eds.), The Handbook of communication science (2nd ed., pp. 145-163). SAGE Publications, Inc.

Chadwick, A. (2013). The hybrid media system: Politics and power. Oxford University Press. 
Chirawurah, D., Fishkin, J., Santuah, N., Siu, A., Bawah, A., Kranjac-Berisavljevic, G., \& Giles, K. (2019). Deliberation for development: Ghana's first deliberative poll. Journal of Deliberative Democracy, 15(1), 3. https://doi.org/10.16997/jdd.314

Craig, R. (1999). Communication theory as a field. Communication Theory, 9(2), 119-161. https://doi.org/10.1111/j.1468-2885.1999.tb00355.x

Crandinetti, F. (2008). Political elites. In K. Warren (Ed.), Encyclopedia of U.S. campaigns, elections, and electoral behavior (pp. 517-517). SAGE. https://doi.org/10.4135/9781412963886

Dahlgren, P. (2005). The Internet, public spheres, and political communication: Dispersion and deliberation. Political Communication, 22(2), 147-162. https://doi.org/10.1080/10584600590933160

Delli Carpini, M. X., Cook, F. L., \& Jacobs, L. R. (2004). Public deliberation, discursive participation, and citizen engagement: A review of the empirical literature. Annual Review of Political Science, 7(1), 315-344. https://doi.org/10.1146/annurev.polisci.7.121003.091630

Druckman, J. N., \& Nelson, K. R. (2003). Framing and deliberation: How citizens' conversations limit elite influence. American Journal of Political Science, 47(4), 729-745. https://doi.org/10.1111/1540-5907.00051

Dryzek, J. S., Bächtiger, A., Chambers, S., Cohen, J., Druckman, J. N., Felicetti, A., Fishkin, J. S., Farrell, D. M., Fung, A., Gutmann, A., Landemore, H., Mansbridge, J., Marien, S., Neblo, M. A., Niemeyer, S., Setälä, M., Slothuus, R., Suiter, J., Thompson, D., \& Warren, M. E. (2019). The crisis of democracy and the science of deliberation. Science, 363(6432), 1144-1146. https://doi.org/10.1126/science.aaw2694

Eveland, W. P., Morey, A. C., \& Hutchens, M. J. (2011). Beyond deliberation: New directions for the study of informal political conversation from a communication perspective. Journal of Communication, 61(6), 1082-1103. https://doi.org/10.1111/j.1460-2466.2011.01598.x

Fishkin, J. S., \& Laslett, P. (2003). Debating deliberative democracy (Vol. 7). Blackwell.

Fishkin, J. S., \& Luskin, R. C. (2005). Experimenting with a democratic ideal: Deliberative polling and public opinion. Acta Politica, 40(3), 284-298.

Global Media Journal México 17(33). julio - diciembre 2020. Pp. 1-19. 
Glover, T. D. (2018). Ordinary political conversation in seemingly nonpolitical leisure: All talk and no action? Leisure Sciences, 40(7), 723-734. https://doi.org/10.1080/01490400.2018.1534626

Goodin, R. E. (2012). How can deliberative democracy get a grip? The Political Quarterly, 83(4), 806-811. https://doi.org/10.1111/j.1467-923X.2012.02356.x

Goodin, R. E. (2017). The epistemic benefits of deliberative democracy. Policy Sciences, 50(3), 351-366. https://doi.org/10.1007/s11077-017-9286-0

Habermas, J. (1962). The structural transformation of the public sphere: An inquiry into a category of bourgeois society. MIT Press.

Habermas, J. (1985a). The theory of communicative action, Volume 1: Reason and the rationalization of society (T. McCarthy, Trans.). Beacon Press.

Habermas, J. (1985b). The theory of communicative action, Volume 2: Lifeworld and system: A critique of functionalist reason (T. McCarthy, Trans.). Beacon Press.

Habermas, J. (2006). Political communication in media society: Does democracy still enjoy an epistemic dimension? The impact of normative theory on empirical research. Communication Theory, 16(4), 411-426. https://doi.org/10.1111/j.14682885.2006.00280.x

Ikeda, K., \& Boase, J. (2011). Multiple discussion networks and their consequence for political participation. Communication Research, 38(5), 660-683. https://doi.org/10.1177/0093650210395063

Kim, H. M., \& Baek, Y. M. (2018). The power of political talk: How and when it mobilizes politically efficacious citizens' campaign activity during elections. Asian Journal of Communication, 28(3), 264-280. https://doi.org/10.1080/01292986.2018.1431295

Kim, J., \& Kim, E. J. (2008). Theorizing dialogic deliberation: Everyday political talk as communicative action and dialogue. Communication Theory, 18(1), 51-70. https://doi.org/10.1111/j.1468-2885.2007.00313.x

Kim, J., Wyatt, R. O., \& Katz, E. (1999). News, talk, opinion, participation: The part played by conversation in deliberative democracy. Political Communication, 16(4), 361385. https://doi.org/10.1080/105846099198541

Global Media Journal México 17(33). julio - diciembre 2020. Pp. 1-19. 
Kim, N., Fishkin, J. S., \& Luskin, R. C. (2018). Intergroup contact in deliberative contexts: Evidence from deliberative polls. Journal of Communication, 68(6), 1029-1051. https://doi.org/10.1093/joc/jqy056

Larrosa-Fuentes, J. S. (2017). The political communication systems model. En Communication and the Body Politic: Hillary Clinton's 2016 Presidential Campaign in Philadelphia's Latino Community (pp.20-43) [Tesis Doctoral, Temple University]. http://digital.library.temple.edu/cdm/ref/collection/p245801 coll10/id/507196

Manning, J. (2020). Interpersonal communication. In D. L. Merskin (Ed.), The SAGE International Encyclopedia of Mass Media and Society (Vol. 2, pp. 842-845). Sage Publications.

Martín Serrano, M. (1994). La comunicación pública y la supervivencia. Diálogos de La Comunicación, 39, 5-11. https://eprints.ucm.es/13246/

McLeod, D. M., Kosicki, G. M., \& McLeod, J. M. (2008). Political Communication Effects. In J. Bryant \& M. B. Oliver (Eds.), Media Effects: Advances in Theory and Research (pp. 228-251). Taylor \& Francis.

Morey, A. C., \& Yamamoto, M. (2020). Exploring political discussion motivations: Relationships with different forms of political talk. Communication Studies, 71(1), 78-97. https://doi.org/10.1080/10510974.2019.1692885

Pennington, N., \& Winfrey, K. L. (2020). Engaging in political talk on Facebook: Investigating the role of interpersonal goals and cognitive engagement. $\begin{array}{lll}\text { Communication } & \text { Studies, } & 0(0),\end{array}$ https://doi.org/10.1080/10510974.2020.1819844

Rojas, H., Shah, D. V., \& Friedland, L. A. (2011). A communicative approach to social capital. Journal of Communication, 61(4), 689-712. https://doi.org/10.1111/j.14602466.2011.01571.x

Settle, J. E., \& Carlson, T. N. (2019). Opting out of political discussions. Political Communication, 36(3), 476-496. https://doi.org/10.1080/10584609.2018.1561563

Shah, D. V., Cho, J., Nah, S., Gotlieb, M. R., Hwang, H., Lee, N.-J., Scholl, R. M., \& McLeod, D. M. (2007). Campaign ads, online messaging, and participation: Extending the communication mediation model. Journal of Communication, 57(4), 676-703. https://doi.org/10.1111/j.1460-2466.2007.00363.x

Global Media Journal México 17(33). julio - diciembre 2020. Pp. 1-19. 
Shugars, S., \& Beauchamp, N. (2019). Why keep arguing? Predicting engagement in political conversations online. SAGE Open, 9(1), 2158244019828850. https://doi.org/10.1177/2158244019828850

Sørensen, M. P. (2016). Political conversations on Facebook - the participation of politicians and citizens. Media, Culture \& Society, 38(5), 664-685. https://doi.org/10.1177/0163443715620924

Stromer-Galley, J. (2002). New voices in the public sphere: Political conversation in the Internet age [Ph.D., University of Pennsylvania]. http://search.proquest.com.libproxy.temple.edu/docview/305534103/abstract?accou ntid $=14270$

Stromer-Galley, J. (2004). Interactivity-as-product and interactivity-as-process. The Information Society, 20(5), 391-394. https://doi.org/10.1080/01972240490508081

Valeriani, A., \& Vaccari, C. (2018). Political talk on mobile instant messaging services: A comparative analysis of Germany, Italy, and the U.K. Information, Communication \& Society, 21(11), 1715-1731. https://doi.org/10.1080/1369118X.2017.1350730

Valo, M. (2011). What is mobile interpersonal communication? Interactions: Studies in Communication \& Culture, 3(1), 3-7. https://doi.org/10.1386/iscc.3.1.3_2

Vliegenthart, R., \& Zoonen, L. van. (2011). Power to the frame: Bringing sociology back to frame analysis. European Journal of Communication, 26(2), 101-115. https://doi.org/10.1177/0267323111404838

Wright, S., \& Street, J. (2007). Democracy, deliberation and design: the case of online discussion forums. New Media \& Society, 9(5), 849-869. https://doi.org/10.1177/1461444807081230

Wyatt, R., Katz, E., \& Kim, J. (2000). Bridging the spheres: Political and personal conversation in public and private spaces. Journal of Communication, 50(1), 71-92. https://doi.org/10.1111/j.1460-2466.2000.tb02834.x

Global Media Journal México 17(33). julio - diciembre 2020. Pp. 1-19. 